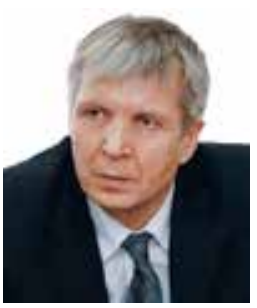

Aleksandr P. SUKHODOLOV Dr. Sc. (Econ.), Professor, Rector

Baikal State University 664003, RF, Irkutsk, Lenina St., 11

Phone: (395) 252-26-22

E-mail: rector@bgu.ru

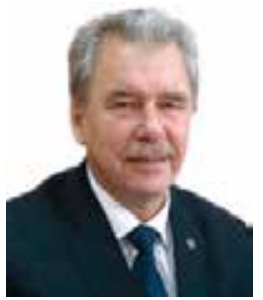

Yury M. BERYOZKIN

Dr. Sc. (Econ.), Professor of Finance Dept.

\section{Baikal State University 664003, RF, Irkutsk, Lenina St., 11 \\ Phone: (395) 252-00-08 \\ E-mail: finans@bgu.ru}

\section{Keywords}

INSTITUTIONAL ECONOMY

TRANSACTION COSTS

FINANCIAL CRISIS

IMPACT INVESTING IN TANGIBLE ASSETS

DIGITAL PLATFORMS

FINTECH

\title{
From the Institutional to the Platform Economy
}

\section{References}

The article analyses the processes that are widely known in the literature as "the financial-technological revolution", or FinTech. It shows that these processes derive from the global financial crisis of 2007-2008 that turned out to be a crisis of the institutional economy, or "the economy of transactions". The authors determine the main directions for overcoming the crisis which over the past 10 years have formed new mainstream: a transition to Impact Investing aimed at implementing not only market values, but also socio-economic ones - Shared/Blended Values. The technological basis for new mainstream was the development of the third-level machines and technologies that are above energy and information technologies, i.e. value machines, or Intangible. In practice, FinTech is already undergoing rapid development in China and the West on the basis of digital platforms that eliminate transaction costs and generate added value and capitalization of property. The authors formulate the anticipated consequences of FinTech.

\section{INTRODUCTION.}

\section{THE ECONOMY OF TRANSACTIONS}

From the perspective of Neoclassical Economic Theory (Economics) [15], which transformed into the economic mainstream after the World War II, the model of the market economy can be briefly characterized as follows. There exist numerous free actors ("atomic" businesses) that produce goods and services and launch them into the market, where prices are formed in accordance with the current supply-demand ratio. By making monetary policy more strict or liberal, monetary authorities introduce management adjustments to market relations between economic actors: boosting market demand when there is a decline in economic growth, or, conversely, reducing it in situations of "overheating" of the economy. The primary task of science is to find ways to minimize resources consumed in the process of production. At that, several fundamental theoretical assumptions are accepted, and one of the most important of them is the assumption about the absence (economic insignificance) of transaction costs [3. P. 2; 10. P. 64; 13. P. 6].

The term "transaction" was coined by J. Commons in 1931 [28]. Transaction refers to any supporting activity, which in itself is not of a productive nature, but crucially important for the main activity. Transactions are involved in all forms of activity associated with registration, control, acquisition and alienation of property rights (for goods, property and assets) and implementation of freedoms of modern society. Accord- ing to J. Commons, there are three types of transactions: (a) bargaining transaction; (b) managerial transaction; and (c) rationing transaction (distributing goods, granting rights). By now, more detailed typologies and classifications of transactions have been developed [2; 8]. J. Commons was the founding father of a vast scientific discipline - institutional economics, or institutionalism, that focuses on formal and informal norms and rules for implementation of various types of transactions.

Neoclassical economics recognizes the existence of institutions in modern society (state institutions, administrative law institutions, civil society institutions and economic (financial) institutions), but regards them as a "convenient environment" for people's life and activity that does not pose obstacles in the process of exchange between economic actors. In other words, exchange relationships (transactions) are not accompanied by any economic losses (costs). This is one of the initial premises embedded in the neoclassical economic theory.

In his famous article "The Nature of the Firm" (1937) ${ }^{1}$, R. Coase [6] introduced the term "transaction costs", i.e. costs that accompany the interaction between economic entities, thereby transferring the problem of transactions and public institutions from the legal (as stated by J. Commons) into

${ }^{1}$ Fifty-four years later, in 1991, Ronald Coase was awarded the Nobel Prize in Economic Sciences for discovery and clarification of the significance of transaction costs and property rights for the institutional structure. 
Статья посвящена анализу процессов, получивших в литературе название «финансово-технологическая революция", или "финтех". Показано, что эти процессы были порождены мировым финансовым кризисом 2007-2008 гг, который по своей сути оказался кризисом институциональной экономики, или "экономики трансакций". Выделены основные направления преодоления кризиса, которые за последние 10 лет оформились в новый мейнстрим: переход к проектному соинвестированию материальных активов, ориентированному на реализацию не только рыночной ценности, но и социально-экологической. Технологической основой нового мейнстрима стала разработка машин и технологий третьего уровня, надстраиваемых над энергетическими и информационными, - стоимостных, или Intangible. В практическом отношении "финтех" уже бурно развивается в Китае и на Западе на цифровых платформах, снижающих трансакционные издержки и обеспечивающих прирост добавленной стоимости и капитализации собственности. Сформулированы ожидаемые последствия "финтеха".

the economic field. This phenomenon was called "neo-institutionalism"1. Later, Coase's ideas were further advanced in the works of his followers - A. Alchian [1], D. North [12], O. Williamson [18], S. Cheung [27] and H. Demsetz [29].

Not only the aforementioned researchers but also many other scholars have found that transactions in economics always create effects reminiscent of friction in physics ( $K$. Arrow) that add higher or lower transaction costs to the transformation costs (due to the conversion of raw materials into finished products). At that, as the social division of labour evolves and the numbers of various intermediaries in economic relations constantly grow, the share of the latter (in total costs) is becoming increasingly significant. Moreover, the greater the potential hazard of the produced products is or the more technologically complex they become, the greater the share of transaction costs that might reach very

${ }^{1}$ Ronald Coase was highly critical of American economic mainstream. In the article "Saving Economics from the Economists", he wrote: "In the 20th century, economics consolidated as a profession; economists could afford to write exclusively for one another. At the same time, the field experienced a paradigm shift, gradually identifying itself as a theoretical approach of economization and giving up the real-world economy as its subject matter. Today, production is marginalized in economics, and the paradigmatic question is a rather static one of resource allocation. The tools used by economists to analyze business firms are too abstract and speculative to offer any guidance to entrepreneurs and managers in their constant struggle to bring novel products to consumers at low cost". URL: http://hbr-russia.ru/biznes-i-obshchestvo/fenomeny/a11518/\#ixzz44BshevCG. high levels - from $70 \%$ (nuclear reactor) to $90 \%$ (medicines). The costs of legal institutions' transactions increase if in the country there are a "gray" economy, corruption and similar illegitimate relations [4].

The development of neo-institutionalism and massive empirical studies performed within its framework helped to understand the indisputable fact that the modern developed economy should be better called "institutional economy", or the "transaction economy" [4; 24]. The main reason behind the severe global financial crisis of $2008^{2}$ was the onerous burden of transaction costs accumulated in the world economy (primarily in the US) which undermined the financial sector of economy in the first place. This was due to the collapse of the four "pillars" of the global financial system - the largest investment banks that had more than a one-hundred-year history and capitalization exceeding 10 trillion US dollars - Lehman Brothers, Merrill Lynch, Goldman Sachs and Morgan Stanley ${ }^{3}$ [21].

\section{TRANSACTIONS ARE THE ELEMENTARY FABRIC OF PROPERTY}

The problems of the institution of property are closely related to the problems of

${ }^{2}$ No one of economic mainstream's representatives managed to anticipate the 2008 financial crisis [5. P. 10]. We suppose that the major reason behind the failure of mainstream economics lies in ignoring transaction costs that played a decisive role in the emergence of the crisis.

${ }^{3}$ The first and largest two banks ceased to exist, whereas Goldman Sachs and Morgan Stanley, while keeping their brands, lost their independence and investment profile and were acquired by other banks.
СуХОАОЛОВ Алексанар Петрович Аоктор экономических наук, профессор, ректор

\section{Байкальский государственный университет 664003, РФ, г. Иркутск, ул. Менина, 11 \\ Ten.: (395) 252-26-22 \\ E-mail: rector@bgu.ru}

БЕРЁЗКИН Юрий Михайлович Аоктор экономических наук, профессор кафедры финансов

\section{Байкальский государственный университет 664003, РФ, г. Иркутск,}

ул. Менина, 11

Ten.: (395) 250-00-08

E-mail: finans@bgu.ru

Ключевbе слова

ИНСТИТУЦИОНАЛЬНАЯ ЭКОНОМИКА

ТРАНСАКЦИОННЫЕ ИЗДЕРЖКИ

ФИНАНСОВЫЙ КРИЗИС

ПРОЕКТНОЕ СОИНВЕСТИРОВАНИЕ

МАТЕРИАЛЬНЫХ АКТИВОВ

ЦИФРОВЫЕ ПЛАТФОРМЫ

«ФИНТЕХ» 


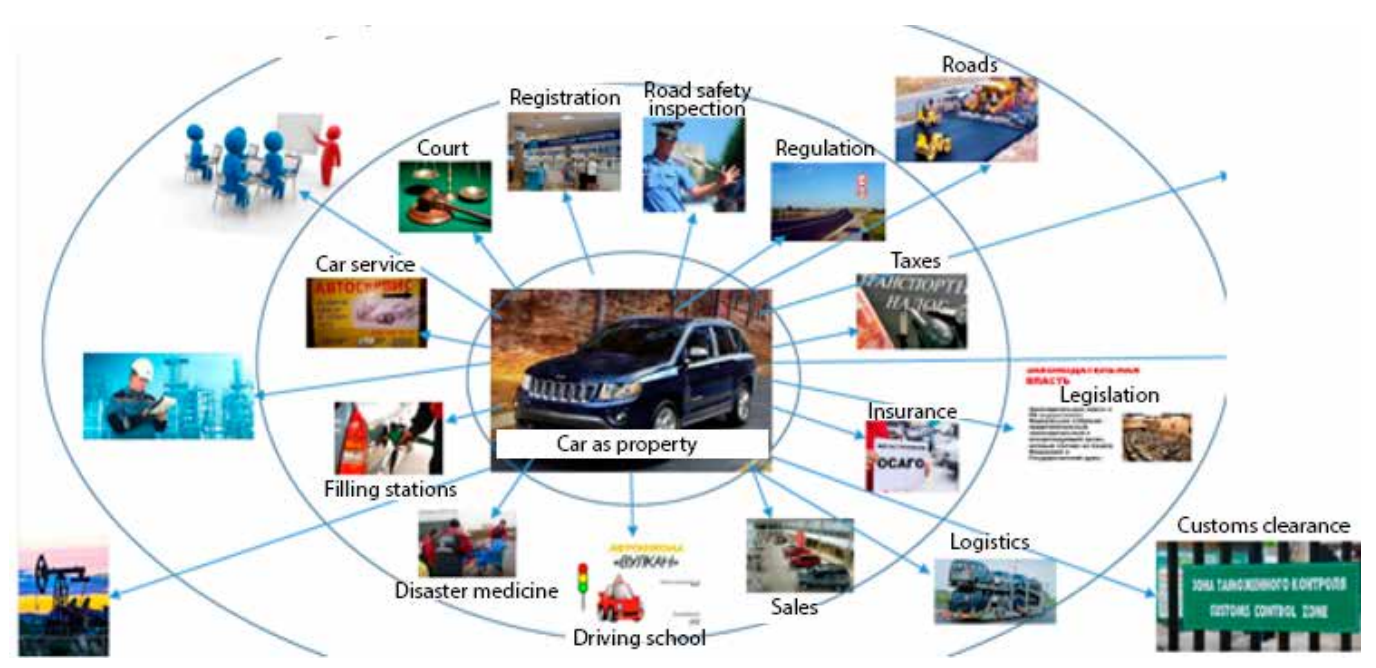

Fig. 1. Part of the transactions alienating the property of a car

transaction costs [4]. In Russia, property is interpreted exclusively as personal effects that are subject to the right of possession and disposal, as well as the right of using the effects for one's own purposes ${ }^{1}$. From the methodological [14. P. 63; 26. P. 290] and institutional $[4 ; 7]$ perspectives, such a "naturalistic" understanding of property relations has long been outdated and does not stand up to criticism. Property relations are an extremely complex and multilayered notion within the framework of which private possessions are only at a bottom sensually perceived layer. The layer, opposite to the property one, is Plato's property eidos. Between these two poles, there are a multilayered fabric of ever-complicating institutionalized relations of mediation that are generated by possessing, disposing of and using property ${ }^{2}$.

${ }^{1}$ The Civil Code of the Russian Federation. Part 1. Art. 209, 244.

${ }^{2}$ According to Hernando de Soto, "property is not an element of the material world; it belongs to the sphere of law and economics" [4. P. 74].
Institutional ideas about property relations proceed from Karl Marx's views ${ }^{3}$. He showed that the alienated labour of workers created the basis for the capitalist's private property to exist. Later, the institutionalists developed this theoretical position of the classic author. Ronald Coase's ingenious discovery was the understanding that the fabric of the property relations is woven from transactions. Every transaction alienates a piece of property. The entire set of transaction costs can significantly exceed the value of the property that is owned, disposed of and used by the owner. Fig. 1 illustrates this using the simple case of a car as property.

3 "We have arrived at the concept of private property through an analysis of the concept of estranged, alienated labour... Although private property appears as the basis and cause of alienated labour, it is in fact its consequence... It is only when the development of private property reaches its ultimate point of culmination that this, its secret, reemerges; namely, that is (a) the product of alienated labour, and (b) the means through which labour is alienated, the realization of this alienation [9. P. 97].
Fig. 1 conditionally demonstrates that, once a car is classified as property, its owner is surrounded by numerous institutional structures that create an opportunity of possessing, disposing of and using the car and force the owner to obey numerous rules [25]. Nevertheless, all this comes at a price. Services (transactions) are accompanied by transaction costs incurred by the owner. Over time, the number of these transactions is growing, as well as the accompanying costs are becoming more extensive. In the fields where institutions are not developed, transaction costs generate illegal relationships, including crime [4].

The same is true for any economic transaction (Fig. 2). To make even the simplest deal possible and legitimate, a large number of transactions should be involved: lending, notary services, arbitration, business lawyers, the tax service, financial and administrative control, the Department for Fighting Against Economic Crimes and even services included in the so-called

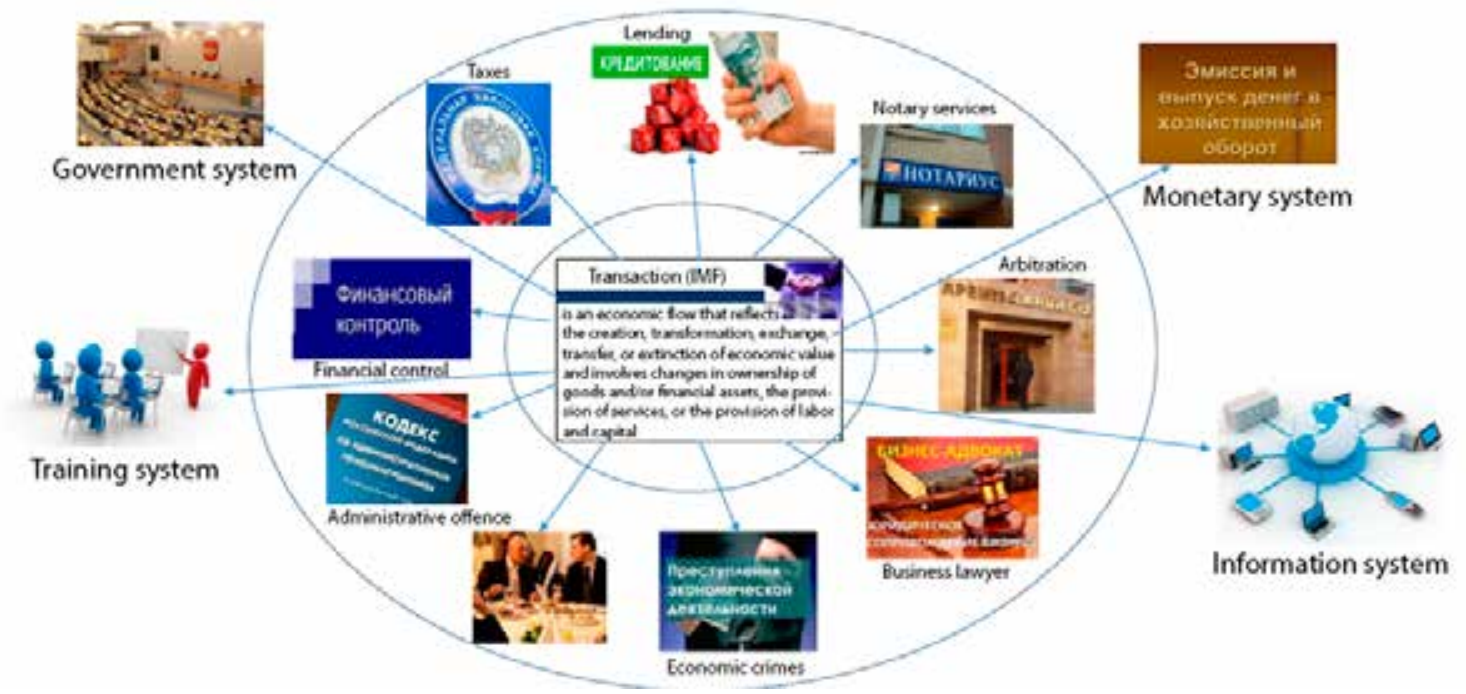

Fig. 2. Transactions accompanying a business deal 
"hospitality costs" (flights, hotels, restaurants, etc.). All of them are often accompanied by significant transaction costs.

The next level of these transactions is formed by the system of government authorities, the monetary system of the state, the information system, the training system, etc. We have mentioned by no means all the transactions that ensure and accompany the most elementary economic deal.

According to Marx, overcoming the alienation of labour and property should be executed through elimination of alienation (aufheben). The German word "aufgeben" suggests not just eradicating private property, but "eradicating with preservation", the obtaining of property. At that, Marx believed that the process of overcoming alienation should be conducted in reverse order (as to how alienation took shape and became more complicated historically) [9. P. 113]. In the terms of the neo-institutional theory, this Marx's thesis means the obtaining of property through gradual removal of transaction costs ${ }^{1}$. Waged labour should be eventually eliminated, and all workers should turn into full-fledged owners gradually eradicating various transactions and their accompanying costs [9].

\section{IMPACT INVESTING}

WITH VALUE OVERTONES

Return to the landmark events of 2008. After the collapse of the four system-forming investment banks - in October and November - the Rockefeller Foundation instituted its Impact Investing Initiative and allocated significant financial resources for that. One month earlier, Satoshi Nakamoto $^{2}$ had published the sensational article "Bitcoin: A Peer-to-Peer Electronic Cash System" [11]. The former gave rise to a new mainstream in investment activities - the so-called impact investing in tangible assets on the basis of Shared/Blended Value ${ }^{3}$. The latter produced "FinTech" - a technological basis for the platform economy.

The point of impact investing is to invest in a project not money, but those tangible assets that allow producing added value, while avoiding a greater or lesser range of transactions (and transaction costs) - bank

${ }^{1}$ In this sense, neo-institutionalism is radically different from economic neoclassic: economics focuses on reducing transformation costs by improving the technologies for the reprocessing of raw materials; neo-institutionalism is centred upon the removal of transaction costs through digital platforms and the socalled "FinTech", i.e. cost technologies.

${ }^{2}$ This is probably a pseudonym for a group of people who do not want to publish their real names.

${ }^{3}$ By 2015 , every sixth dollar of world investment was implemented on the principles of impact investing. transactions, tax transactions, control transactions, etc.

One more event of 2008 facilitated a fast spread of the Impact Investing practice. In July, the University of Chicago (USA) held the international scientific-practical conference "China's Economic Transformation" that was opened and cochaired by the neo-institutionalism maître Ronald Coase $^{4}$. For five days, the world economic elite were discussing the issues that were almost resolved by China after 30 years of economic reforms, which made the Chinese economy comparable in scale to the US economy. In the course of the discussion, it was revealed that Adam Smith's "The Wealth of Nations" [16] and "The Theory of Moral Sentiments" ${ }^{5}$ [17] and Ronald Coase's institutional theory of transaction costs [6] were adopted by China as the theoretical basis for its economic reforms. From the very beginning, the country's economic transformations were aimed at dealing with property $^{6}$. Local residents together with authorities of literally every community (county, municipality) sought such rules of dealing with property (which formally remained state-owned) that would have minimized transaction costs (obstacles to the growth of added value) and turned workers (as well as government officials) into owners [7].

After the Chicago Conference, economic thought of the West started following the same path. Within a short space of time, there even emerged a special class of investors (there are already millions of them) called "High-Net-Worth Individuals" (HNWI) [21] - they are very wealthy people preferring not to be involved in charity but along with that not wishing to make investments just for profit (market values). They would like to invest money in such a way so that they could earn profit and simultaneously realize their social and ecological values making the world a better place - Shared Value, or Blended Value. Currently, this type

${ }^{4}$ At that time, Ronald Coase was 98 years old. Four years later, in 2012, based on the materials of the conference, Ronald Coase and Nina Wan published their book "How China Became Capitalist" which immediately became a world bestseller [7].

${ }^{5}$ In his interview to Financial Times on February 2 2009, Wen Jiabao, the Premier of the State Council of the People's Republic of China, said that according to Adam Smith, there are two invisible hands in economy: one, he refers to the market; the other, he talks about morality. At that, since the time of Confucius, the Chinese have interpreted morality as not artificially imposed norms, but as a historically developed "spirit of a place" where specific people lived [21].

${ }^{6}$ Legal property is a necessary process of linking and deploying capital... Without using the mechanisms of property, humanity is unable to instill the fruits of their labour with the patrimonial essence that allows differentiating them, combining and investing in order to produce additional values [4. P. 79]. of investment is already worth many trillion dollars and carried out mainly in poor regions of the world - Africa, Latin America and Southeast Asia.

\section{VALUE MACHINES - THE THIRD LEVEL OF TECHNOLOGY}

During the past two or three years, the Russian mass media and economic literature have been discussing the digital economy. According to many experts and government officials, its creation will help Russia to take its rightful place among the advanced countries of the world. For that purpose, in the summer of 2017, the longrange program "The Digital Economy of the Russian Federation" was officially adopted ${ }^{7}$.

But there is an alternative point of view. For example, S.B. Chernyshyov (and we support his views) considers the term "digital economy" to be unsatisfactory [24], and the main world trends in the modern technological development have already made their way, albeit related to "digits" (indirectly) but in a completely different manner.

As mentioned above, Satoshi Nakamoto's article on bitcoin ${ }^{8}$ and the publication of the protocol for deploying the world's peer-to-peer blockchain network started the world's technological mainstream. Without going into the technical details of a blockchain (this is the task of IT specialists), let us briefly name the opportunities that the blockchain technology opens up in the context of the world financial (economic) revolution that is happening before our very eyes.

Specialists in the field of institutional engineering, such as S.B. Chernysyhov, Yu. A. Milyukov, V.Yu. Rumyantsev [20; 23] and $\mathrm{H}$. de Soto [4], distinguish between the two types of technologies developed in the past century. The first type is energy technology that has long been used in modern society (thermal, electrical, nuclear and other machines and all kinds of devices).

${ }^{7}$ The program "The Digital Economy of the Russian Federation". URL: http://static.government.ru/media/files/9gFM4FHj4PsB7915v7yLVuPgu4bvR7M0.pdf.

${ }^{8}$ Just to make it clear, it is worth mentioning that the authors do not share the current enthusiasm about the prospects and possibilities of bitcoin as a new type of money (decentralized cryptocurrency) which is supposedly capable of supplanting fiat money from the world economic turnover (dollar, etc.). Despite the current high rate of bitcoin against dollar, it is only the first and imperfect (trial) version of cryptocurrencies that are already being developed in several countries (China, Japan, etc.). Bitcoin is nothing more than a convenient speculative investment tool. In this capacity, it will probably be used for some time to inflate a financial bubble. In the future, bitcoin technology can be very useful but in a completely different function - ensuring that information in local lock-up networks remains unchanged (see URL: https://hightech.fm/2018/01/25/Vavilov). 
on In general, they perform four functions: $\approx$ they generate energy from natural resourco. es, transform it from one form to another, $\infty$ accumulate and transmit it. The era of Nechnology of the second type - informa푸 tion technology - began half a century ago (starting from 1947, when J. von Neumann developed the first computer architecture). We all are already used to computers and the Internet working on this type of technology - information (or "digital")'. At the same time, information technology in each specific information system is above the energy technology - "soft" over "hard" - and carries out the same four functions (but in relation to information): it extracts information from the environment, converts it from one form to another, accumulates and transmits it. Thanks to Satoshi Nakamoto, the technology of the third type (with the unsettled name "FinTech", or Intangible) is now experiencing a rapid growth $[21 ; 22$; 25] (Fig. 3).

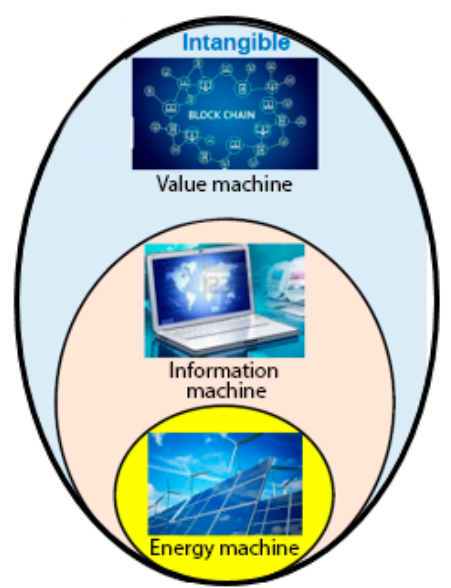

Fig. 3. Three-level value machine Intangible
In turn, these technologies are above the information machine, i.e. "digital" one. Blockchain serves as a kind of "hard", and special software complexes - "digital platforms" serve as "soft". The purpose of the third technological "floor" is to visualize the processes of extracting value (producing added value), transforming it into other forms, accumulating and transferring value $^{2}$. At the same time, platforms are subject to standardization so that they could be the basis for various services (banking ${ }^{3}$, insurance, notary, registration, cadastral, etc.) or entrepreneurial projects premised on the principles of co-investment in tangible assets collected in "bundles" for generating added value (Impact Investing). For each such platform to operate successfully, it should contain the three functional blocks: 1) a database (Big Data) of a large number of tangible assets with their specifications; 2) optimization algorithms for building the most efficient (in terms of eliminating transaction costs) chains of assets; 3 ) a software package for clearing payments between the participants of impact investing in assets ${ }^{4}$.

\section{CONCLUSION: POSSIBLE CONSEQUENCES}

The financial and technological revolution is expected to lead to far-reaching consequences, many of which will not be treated as positive. In accordance with Marx's calculations (on eliminating alienation of property in reverse order), a massive eradication of transactions has already started with banks ${ }^{5}$ [19]. World banks, realizing that their "collapse" is inevitable, decided to control this process though aggressive development of digital banking platforms.

Large groups of intermediaries, such as government officials, inspectors, notaries, various kinds of registers, insurers, accountants, etc. will begin to disappear. All their functions are easier and cheaper to fulfil through the use of digital platforms. Next, fiat money will be replaced with the clearing payment tools on the platforms of various types. They will take the form of cryptocurrency that is the most appropriate for working in blockchain networks and digital platforms ${ }^{6}$

In a slightly more distant future, it will come to the removal of transactions generated by the institution of the state per $\mathrm{se}^{7}$. With the development of entrepreneurship based on impact investing in tangible assets, such kind of activity as "business" will become marginalized, and in the end, it will vanish as inefficient. Along with that, the very concept of "market economy" ("transaction economy") will not be in use any more. "Islands of conscious power", mentioned by Coase [6. P. 38] when talking about an individual firm, will reach the size of the world's blockchain networks.

Accordingly, the system of education and vocational training should be subjected to fundamental change: modern economists and specialists in economic law will gradually "die out like mammoths", whereas professionals capable of setting meaningful tasks for the platform economy will be in high demand.

${ }^{1}$ In this sense, the development of the "digital economy" in the Russian Federation does not presuppose any new technological revolution. Globally, the information revolution has long happened. The Program, adopted in 2017, employs only a catch-up strategy - the elimination of accumulated backlogs in information technology. At that, we are again at risk of missing the new technological leap of "FinTech" that has already begun in the world and is developing at a rate of $300-400 \%$ a year.

2 "Capital proceeded from the ability of the West to utilize legal property systems as a mechanism for virtual reflection of resources. Only within the virtual plane, the minds of different people can deal with the question of using resources with the best result for humanity... For millennia, the Greatest Minds have been convincing us that different levels of reality are possible and many of them are invisible, therefore, to comprehend them, special tools are needed to convert them into a form that can be perceived" [4. P. 80].

${ }^{3}$ A striking example is the blockchain platform CORDA, developed by R3 consortium of 42 major world banks and 40 financial institutions [21]. Another example is the Landing Club micro-credit platform (see URL: http://bankir.ru/publikacii/20160524/lending-club-moshenniki-osedlavshie-fintekh-10007584).

${ }^{4}$ Special units of account (cryptocurrency), "as an internal function block", are necessary exactly for performing the third function - clearing payments [21]. In particular, in 2017, The People's Bank of China announced the development of Cryptoyuan. The Central Bank of the Russian Federation also studies the issue of developing Cryptoruble. The principal difference between cryptocurrency and fiat money is that the former will be controlled: it will have a mark of its intended use. Due to that, cash flows are guaranteed full transparency and protection against all kinds of fraud and misuse.

${ }^{5}$ In his interview to TASS News Agency on May 26, 2016, Assistant to President Putin A. Belousov said, "In the near future, the banking system will not perform the function that it has to perform in the economy, namely, to transform savings into loans and investments. It is basically busy with itself, if I may say so. Neither the stock market nor the banking sector works. In the next two years, we have to do a lot of work to create a range of investment tools other than bank lending. We will not see any growth, otherwise" (see URL: http://tass.ru/opinion/interviews/3314575). Speaking in Skolkovo, the Chairman of the Executive Board of Sberbank of Russia H. Gref also claimed, "The modern banking system will eventually die and customers will open accounts directly in the Central Bank... All functions can be gradually replaced with algorithms ... the banking system will become one-level, i.e. the Central Bank and that is all. We all open accounts in the Central Bank, and the rest is a mere formality".

${ }^{6}$ The Soviet non-cash ruble emerged as a calculated coefficient for servicing the "United all-Union factory» (V. Lenin), i.e. the National Economy of the USSR, in which there were no market relations. This was an early prototype of cryptoruble.

${ }^{7}$ Since 2016, a group of specialists from DayLight has been developing a single international blockchain platform that implements the four basic functions necessary for effective introduction of blockchain technology to most types of government and business activities - financial system, government register structure, Smart contract execution algorithm and Smart laws execution mechanism (see URL: https://forklog.com/komanda-daylight-sozdast-gosudarstvo-na-blokchejne/). 


\section{Источники}

1. Алчиан А. Право собственности // Экономическая теория / под ред. Дж. Итуэлла. М.: ИНФРА-М, 2004. С. 714-723.

2. Аузан А.А. Институциональная экономика. М.: ИНФРА-М, 2005.

3. Бригхем Ю., Гапенски Л. Финансовый менеджмент: полный курс в 2 т. СПб.: Экономическая школа, 1997. Т. 1.

4. Де Сото Э. Загадка капитала. Почему капитализм торжествует на Западе и терпит поражение в остальном мире. М.: Олимп-Бизнес, 2004.

5. Ефимов В.М. Экономическая наука под вопросом: иные методология, история и исследовательские практики. М.: КУРС: ИНФРА-М, 2016.

6. Коуз Р. Природа фирмы // Фирма, рынок и право. М.: Новое издательство, 2007. С. 36-57.

7. Коуз Р., Ван Н. Как Китай стал капиталистическим. М.: Новое издательСТВо, 2016.

8. Кузьминов Я.И., Бендукидзе К.А., Юдкевич М.М. Курс институциональной экономики. М.: Изд. дом ГУ ВШЭ, 2006.

9. Маркс К. Экономико-философские рукописи 1844 г. // Маркс К., Энгельс Ф. Соч. 2-е изд. Т. 42.

10. Маршалл Дж., Бансал В. Финансовая инженерия: полное руководство по нововведениям. М.: ИНФРА-М, 1998.

11. Накамото С. Биткоин: система цифровой пиринговой наличности. URL: https://bitcoin.org/files/bitcoin-paper/bitcoin_ru.pdf.

12. Норт Д. Институты, институциональные изменения и функционирование экономики. М.: Фонд экон. книги «Начала», 1997.

13. Норт Д. Институциональные изменения: рамки анализа // Вопросы экономики. 1997. № 3. С. 6-17.

14. Попов С.В. Организация хозяйства в России. Омск: Курьер, 1999.

15. Самуэльсон П. Экономика: в 2 т. М.: НПО «Алгон», 1993.

16. Смит А. Исследование о природе и причинах богатства народов. М.: Соцэкгиз, 1962.

17. Смит А. Теория нравственных чувств. М.: Республика, 1997.

18. Уильямсон О.И. Экономические институты капитализма. СПб.: Лениздат, 1996.

19. Чернышёв С.Б. Банки больше не нужны. URL: https://www.svoboda. org/a/27733562.html.

20. Чернышёв С.Б. Институциональные истины: производительность. URL: http://expert.ru/2013/12/18/institutsionalnyie-istinyi.

21. Чернышёв С.Б. Кому и зачем нужен блокчейн. URL: http://gefter.ru/ archive/23542.

22. Чернышёв С.Б. Проектное софинансирование: ключ к модернизации производства и возобновлению роста. URL: http://expert.ru/2015/05/15/ proektnoe-sofinansirovanie.

23. Чернышёв С.Б Революция экономических технологий. URL: http:// expert.ru/expert/2016/42/revolyutsiya-ekonomicheskih-tehnologij.

24. Чернышёв С.Б. Техноэкономика. URL: http://ipe-lab.com/articles/218.

25. Чернышёв С.Б Цепи для собственников. Что может дать блокчейн российской экономике. URL: https://lenta.ru/articles/2016/09/22/blockchain_ revolution.

26. Шайхутдинов Р.Г. Охота на власть. М.: МИДИ ПРИНТ, 2005.

27. Cheung St. Will China Go Capitalist? An Economic Analysis of Property Rights and Institutional Change. L.: Institute of Economic Affairs, 1986.

28. Commons J.R. Institutional Economics // American Economic Review. 1931. Vol. 21. P. 648-657.

29. Demsetz H. Cost of Transacting // Quarterly Journal of Economics. 1968. Vol. 81. P. 33-53.

\section{References}

1. Alchian A. Pravo sobstvennosti [The Right of Property]. In: Eatwell J. (ed.) Ekonomicheskaya teoriya [Economic Theory]. Moscow: INFRA-M Publ., 2004. Pp. 714-723.

2. Auzan A.A. Institutsional'naya ekonomika [Institutional Economics]. Moscow: INFRA-M Publ., 2005.

3. Brigkhem Yu., Gapenski L. Finansovyy menedzhment: polnyy kurs $v 2 t$. [Financial Management: A Full Course in 2 Vols.]. St. Petersburg: Ekonomicheskaya shkola Publ., 1997. Vol. 1.

4. De Soto H. The Mystery of Capital: Why Capitalism Triumphs in the West and Fails Everywhere Else (Russ. ed.: De Soto H. Zagadka kapitala. Pochemu kapitalizm torzhestvuet na Zapade i terpit porazhenie v ostal'nom mire. Moscow: OlimpBiznes Publ., 2004).

5. Yefimov V.M. Ekonomicheskaya nauka pod voprosom: inye metodologiya, istoriya $\mathrm{i}$ issledovatel'skie praktiki [Economic Science is in Question: Other Methodology, History and Research Practices]. Moscow: KURS: INFRA-M Publ., 2016.

6. Kouz R. Priroda firmy [Coase R. The Nature of the Firm]. In: Firma, rynokipravo [Firm, Market and Right]. Moscow: Novoe izdatel'stvo Publ., 2007. Pp. 36-57.

7. Coase R., Van N. How China Became Capitalist (Russ. ed.: Kouz R., Van N. Kak Kitay stal kapitalisticheskim. Moscow.: Novoe izdatel'stvo Publ., 2016).

8. Kuz'minov Ya.I., Bendukidze K.A., Yudkevich M.M. Kurs institutsional'noy ekonomiki [The Course of Institutional Economics]. Moscow: HSE Publishing house, 2006.

9. Marks K. Ekonomiko-filosofskie rukopisi 1844 g. [Economic and Philosophical Writings]. In: Marks K., Engel's F. Soch. [Collection of Works]. 2nd ed. Vol. 42.

10. Marshall Dzh., Bansal V. Finansovaya inzheneriya: polnoe rukovodstvo po novovvedeniyam [Financial Engineering: A Comprehensive Guide to Innovation]. Moscow: INFRA-M Publ., 1998.

11. Nakamoto S. Bitkoin: sistema tsifrovoy piringovoy nalichnosti [Bitcoin: A Peer-to-Peer Electronic Cash System]. Available at: https://bitcoin.org/files/ bitcoin-paper/bitcoin_ru.pdf.

12. North D. Institutions, Institutional Change and Economic Performance (Russ. ed.: Nort D. Instituty, institutsional'nye izmeneniya i funktsionirovanie ekonomiki. Moscow: Fond ekon. knigi «Nachala», 1997).

13. North D. Institutsional'nye izmeneniya: ramki analiza [Institutional Changes: The Frames of Analysis]. Voprosy ekonomiki - Issues of Economy, 1997, no. 3, pp. 6-17.

14. Popov S.V. Organizatsiya khozyaystva v Rossii [Organization of Economy in Russia]. Omsk: Kur'er Publ., 1999.

15. Samuel'son P. Ekonomika: v 2 t. [Economics: in 2 vols.]. Moscow: NPO «Algon» Publ., 1993.

16. Smith A. An Inquiry into the Nature and Causes of the Wealth of Nations (Russ. ed.: Smit A. Issledovanie o prirode i prichinakh bogatstva narodov. Moscow: Sotsekgiz Publ., 1962).

17. Smith A. The Theory of Moral Sentiments (Russ. ed.: Smit A. Teoriya nravstvennykh chuvstv. Moscow: Respublika, 1997).

18. Williamson O.E. The Economic Institutions of Capitalism (Russ. ed.: Uil'yamson O.I. Ekonomicheskie instituty kapitalizma. SPb.: Lenizdat, 1996).

19. Chernyshyov S.B. Banki bol'she ne nuzhny [Banks Are No Longer Needed]. Available at: https://www.svoboda.org/a/27733562.html.

20. Chernyshyov S.B. Institutsional'nye istiny: proizvoditel'nost' [Institutional Truth: Economic Perfomrance]. Available at: http://expert.ru/2013/12/18/institutsionalnyie-istinyi.

21. Chernyshyov S.B. Komu i zachem nuzhen blokcheyn [Who and Why Needs Blockchain]. Available at: http://gefter.ru/archive/23542.

22. Chernyshyov S.B. Proektnoe sofinansirovanie: klyuch k modernizatsii proizvodstva i vozobnovleniyu rosta [Shared Investing: The Key to the Modernization of Production and the Resumption of Growth]. Available at: http://expert. ru/2015/05/15/proektnoe-sofinansirovanie.

23. Chernyshyov S.B Revolyutsiya ekonomicheskikh tekhnologiy [Revolution of Economic Technologies]. Available at: http://expert.ru/expert/2016/42/revolyutsiya-ekonomicheskih-tehnologij.

24. Chernyshyov S.B. Tekhnoekonomika [Technoeconomy]. Available at: http://ipe-lab.com/articles/218.

25. Chernyshyov S.B Tsepi dlya sobstvennikov. Chto mozhet dat' blokcheyn rossiyskoy ekonomike [Chains for Owners. What Can the Russian Economy Give to Blockchain?]. Available at: https://lenta.ru/articles/2016/09/22/blockchain_revolution.

26. Shaykhutdinov R.G. Okhota na vlast' [Hunting for Power]. Moscow: MIDI PRINT Publ., 2005.

27. Cheung St. Will China Go Capitalist? An Economic Analysis of Property Rights and Institutional Change. L.: Institute of Economic Affairs, 1986.

28. Commons J.R. Institutional Economics. American Economic Review, 1931, vol. 21, pp. 648-657.

29. Demsetz H. Cost of Transacting. Quarterly Journal of Economics, 1968, vol. 81 , pp. 33-53. 